\title{
Growth performance, blood profile and economic analysis of broilers fed fermented mixture of cassava flour and bovine blood (cassablood) based diets \\ Aniebo, A. O. \\ Department of Animal Science, Chukwuemeka Odumegwu Ojukwu University Igbariam \\ Campus. PMB 6059 Awka Nigeria \\ Corresponding author: okeyphasona@yahoo.com \\ Abstract
}

The effect of dietary treatments on growth performance, haematological and biochemical indices of finisher broilers as well as economics of broiler production were determined in this experiment. Four broiler finisher diets were formulated with different inclusion levels of fermented cassava flour/blood mixture code-named "cassablood". The control diet $\left(T_{\nu}\right)$ contained $0 \%$ cassablood, while diets 2, 3 and 4 contained 20\%, 25\% and 30\% cassablood respectively. 120 four weeks old Anak broiler chicken were randomly allocated the 4 diets with 30 birds per treatment replicated 3 times with ten 10 broilers per replicate in a completely randomized design (CRD). Treatment effects on final body weight, final weight gain, feed intake and feed conversion ratio were significant $(P<0.05)$. Birds fed cassabloodbased diets compared favourably with the control diet. $20 \%$ cassablood inclusion performed equally with the control diet in feed intake, body weight gain and feed conversion ratio. All dietary groups also showed no significant differences $(P>0.05)$ in most haematological and serum biochemical indices of broilers except in cholesterol, glucose and triglyceride contentswhichdiffered $(P<0.05)$ significantly. Similarly, chicken on $20 \%$ and $25 \%$ inclusion levels produced significantly $(P<0.05)$ higher economic gains in terms of feed cost per kilogram of broiler among all the treatments. Therefore, 20 - 25\% cassablood dietary inclusion level was recommended in broiler diet for production and profit maximization.

Keywords: Cassablood, Broilers, Growth performance, Haematology, Serum biochemical indices, Production cost analysis

\section{Introduction}

The poultry industry fell short of its aim of self-sufficiency in animal protein consumption in the country which is presently $5 \mathrm{~g} /$ caput per day and is grossly below recommended level of $35 \mathrm{~g} /$ caput per day (FAO, 2010). Poultry remains excellent source of animal protein to Nigerians. However, potentials of poultry as a panacea to insufficient animal protein intake of Nigerians have not been achieved because of inadequate and expensive feeds. Feed cost, particularly, protein and energy concentrates such as fish meal, soybean meal and maize remains the main factor limiting the development and expansion of poultry farming. Cereals are also very poor in sulfur amino acids especially lysine
(Atteh, 2002), thus requires fortification. The reliable source of these limiting amino acids is fish meal which is scarce and very expensive (Aniebo et al, 2008). There is need to search for sustainable alternatives to replace expensive energy and protein concentrates (Adeyemi, 2005) as a means of lowering feed and total production costs. Blood from abattoir is rich in lysine and is a good source of arginine, methionine, cysteine, leucine but very poor in isoleucine and contains less glycine than either fish meal or soybean meal (Kamalak et al., 2005). Blood when processed into meal, is unpalatable, particularly if overcooked, so care must be taken not to add more than $4 \%$ (Donkoh et al., 2002) or exceed 6\% in poultry ration (Feedipedia, 2015). 
However, Hassan Khan and Ansari (2007) reported unfavorable influence in diets containing more than $3 \%$ blood meal. Also feed intake and body weight gain of broiler chicken were affected. There is then the need to further investigate better methods of processing blood, which is cheaper, more readily and locally available to improve its nutritional value. In addition, there is the need to exploit cheaper energy source like cassava to replace expensive cereals such as maize for livestock production to forestall future food-feed competition.

Cassava meal is rich in energy but poor in protein and sulfur amino acids (Ayasan, 2010). Substantial efforts have been made to replace cereals with cassava in poultry feeding (Oruwari et al., 2003; Aniebo, 2011: Adeyemi et al., 2012). The results, in terms of its feeding value, encountered nutritional problems, physiological response and productive performances of fed chicken on cassava products were of wide variability. Adeyemi et al. (2012) observed that combination of blood meal and cassava meal gave good protein/energy concentrate with better amino acid content. Dustiness and poor protein content in cassava based meal, as well as indigestibility and unpalatability of blood meal could be addressed by absorbing abattoir blood with cassava flour. Nigeria is currently the largest producer of cassava in the world with an annual production of over 34 million tonnes of tuberous roots. Cassava is largely consumed in many processed forms in Nigeria. Its use in the industry and livestock feed is well known (Adeniji et al., 2005) It is estimated that 2.8 million tonnes of cassava was used as feed in 2009 in Ghana (FAO, 2013)and an annual metric tonnes of 45,420 animal blood were generated from various abattoirs in Nigeria in 1991 (Igene 1991) and 90,648 metric tonnes in 2007 (Aniebo et al., 2009) This study was designed to evaluate the effect of mixture of cassava flour and abattoir blood (cassablood) on growth parameters, haematological and biochemical indices as well as the cost benefit for broiler finishers production.

\section{Materials and Methods \\ Location}

The experiment was carried out at the Poultry Research Unit of the Department of Animal Science, Teaching and Research Farm, Chukwuemeka Odumegwu Ojukwu University, Igbariam Campus, Anambra State, South Eastern Nigeria

\section{Source and processing of cassablood}

Peeled, dried cassava (TMS-30555) was milled with a hammer mill of $10 \mathrm{~mm}$ meshsize into floor while fresh cattle blood was collected with clean plastic containers from Odumodu abattoir, Umunya in Oyi LGA, of Anambra State. The cassava floor was mixed with the cattle blood at a ratio of $3: 4$ respectively and sun-dried for four days to $90 \%$ dry matter. The dried crumbs (test ingredient) were ground to a meal with the same hammer mill and code-named "cassablood". Proximate analysis of the processed cassablood was undertaken according to the methods of AOAC (2000). The metabolizable energy (Kcal $/ \mathrm{kg}$ ) of cassablood was estimated using Pauzenga (1985) formula: $\mathrm{ME} \sim 35 \mathrm{xCP} \%+81.8 \mathrm{x}$ $\mathrm{EE} \%+35.5 \times \mathrm{NFE}$

Formulation of cassablood-based experimental diets

Four broiler finisher diets were formulated with different inclusion levels ofcassablood. The control diet $\left(\mathrm{T}_{1}\right)$ contained $0 \%$ cassablood, while diets 2,3 and 4 contained 20, 25 and $30 \%$ cassablood respectively (Table 1). 
Aniebo

Table 1: Composition of experimental diets (\%)

\begin{tabular}{lllll}
\hline Ingredients & \multicolumn{2}{c}{ Treatments } & $\mathbf{T}_{\mathbf{4}}$ \\
\hline Cassablood & $\mathbf{T}_{\mathbf{1}}$ & $\mathbf{T}_{\mathbf{2}}$ & $\mathbf{T}_{\mathbf{3}}$ & 30.0 \\
Maize & - & 20.0 & 25.0 & 35.0 \\
Soybean meal & 50.0 & 38.0 & 35.0 & 20.0 \\
Wheat bran & 31.0 & 27.0 & 25.0 & 5.0 \\
Fish meal & 8.0 & 5.0 & 5.0 & 4.6 \\
${ }^{*}$ Vitamin/mineral premix & 5.0 & 4.6 & 4.6 & 0.5 \\
Bone meal & 0.6 & 0.5 & 0.5 & 3.0 \\
Limestone & 3.5 & 3.0 & 3.0 & 1.0 \\
DL Methionine & 1.0 & 1.0 & 1.0 & 0.2 \\
Lysine & 0.2 & 0.2 & 0.2 & 0.2 \\
Salt & 0.2 & 0.2 & 0.2 & 0.5 \\
Total & 0.5 & 0.5 & 0.5 & 100 \\
Nutrient & 100 & 100 & 100 & 21.63 \\
Crude protein & & & & 2805 \\
M.E Kcal/kg & 21.81 & 21.72 & 21.70 & \\
\hline
\end{tabular}

*Vitamin/Mineral premix to provide the following per kg of diet; Vitamin A, 10,000iu; Vitamin D2, 1,500iu; Vitamin E, 3iu; Vit amin K, 2mg; Riboflavin, 3mg; Vitamin B 12, 0.08mg; Folic acid, 4mg; Mn, 8mg; Zn, 0.5mg; Iodine, 1.0mg; Co, 1.2mg; Cu, 10mg; Fe. 20mg

\section{Experimental birds and management}

One hundred and twenty four-week old Anak broiler chicks were randomly allocated to four diets comprising 30 birds per treatment each. in triplicate of ten broilers per replicate in a completely randomized design (CRD). The birds were housed in deep litter pens. They were reared under similar managerial conditions, and the respective diets were given to experimental birds for 32 days. The experimental diets and clean drinking water were supplied to the birds ad libitum throughout the study period. Prior to the commencement of the experiment, the birds were weighed to obtain their initial body weights and thereafter they were individually weighed at weekly intervals during the experimental period. Parameters measured include; body weight, feed intake and feed conversion ratio. Feed intake was recorded daily. Feed conversion ratio was calculated by dividing the feed intake by weight gain.

Haematological and serum biochemical indices analyses

Blood analysis was carried out at the end of the experiment. Three birds per replicate were randomly selected for blood sample collection. Approximately, $2 \mathrm{mls}$ of blood sample was collected from each of the 3 birds from their webal subclinical veins and transferred to Ethylene Diamine Tetracetic Acid (EDTA) bottles as an anticoagulant for haematological assay (Jain, 1986). Another $2 \mathrm{mls}$ of blood samples was collected into bottles without anticoagulant for serum biochemical indices determinations. The samples were taken to Chukwuemeka Odumegwu Ojukwu University Teaching Hospital Awka for analysis. Blood samples were analyzed according to routinely available clinical methods. The following parameters Packed cell volume (PCV), Haemoglobin, Red blood cell (RBC), White blood cell (WBC), Mean corpuscular volume (MCV), Mean corpuscular haemoglobin concentration (MCHC), Triglyceride, Cholesterol, Total glucose, Total protein, Albumin, Globulin and Differential WBC namely; Monocytes and Neutrophils were evaluated. The PCV was determined using the wintrobe haematocrit method described by Wintrobe (1933). 
Growth performance, blood profile and economic analysis of broilers fed fermented mixture of cassava flour and bovine blood (cassablood) based diets

WBC and RBC were determined using haemocytometer after appropriate dilution (Dacie and Lewis, 1984). Haemoglobin (HB), Mean corpuscular volume (Brown, 1976). Cholesterol was measured (Roshlan and Bernet,1974). The serum protein, albumin and globulin were analysed using SIGMA kits (Feteris, 1965).

\section{Production cost analyses}

The prevailing market prices of the ingredients at the time of study were used to calculate the cost of feed $/ \mathrm{kg}$, total cost of

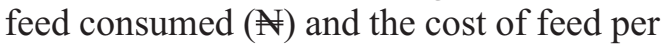
$\mathrm{kg}$ body weight gain ( $)$ of broiler as a means of determining economics of broiler production with cassablood based diets.Feedstuffs were bought at the following rates $(\mathbb{N} / \mathrm{kg}) ; 80 / \mathrm{maize}$; 60/cassava; 50/cassablood; 172/soybean; 50/wheatbran; 20/cattle blood; 140/local fish meal; 100/salt; 520/vitamin/mineral premix; 40/bone meal; 20/limestone; 1,300/methionine; 700/lysine.

\section{Statistical analysis}

Data were subjected to analysis of variance with SAS General Model (2000), and means were separated at $\mathrm{P}<0.05$ using New Duncan's Multiple Range Test as outlined (Obi, 2002).

\section{Results}

The result of the proximate analysis of cassablood meal is presented in Table 2. Effects of the treatments on growth parameters of finisher broilers are shown in Table 3.

Table 2: Analyzed proximate composition of cassablood

\begin{tabular}{ll}
\hline Nutrient & Composition \\
\hline Dry matter (\%) & 83.0 \\
Crude protein (\%) & 29.84 \\
Crude fibre (\%) & 3.5 \\
Fat (\%) & 1.5 \\
Moisture (\%) & 17.0 \\
Ash (\%) & 5.5 \\
Metabolizable energy (Kcal $/ \mathrm{kg})$ & 3,285 \\
\hline
\end{tabular}

Table 3: Effects of dietary cassablood on performance indices of finisher broiler chickens

\begin{tabular}{llllll}
\multicolumn{5}{c}{ Treatments } \\
\hline Parameters & T1 & T2 & T3 & T4 & SEM \\
\hline Feed intake/bird (g) & $4680.0^{\mathrm{a}}$ & $4604.2^{\mathrm{a}}$ & $4546.6^{\mathrm{b}}$ & $4468.3^{\mathrm{c}}$ & $4^{\mathrm{b}}$ \\
Initial weight/bird (g) & $1193.33^{\mathrm{b}}$ & $1166.67^{\mathrm{b}}$ & $1106.67^{\mathrm{c}}$ & $1186.67^{\mathrm{b}}$ & 7.02 \\
Final weight/bird (g) & $3026.67^{\mathrm{a}}$ & $2983.33^{\mathrm{a}}$ & $2803.33^{\mathrm{b}}$ & $2766.67^{\mathrm{c}}$ & 48.42 \\
Weight gain/bird (g) & $1833.33^{\mathrm{a}}$ & $1816.66^{\mathrm{a}}$ & $1696.67^{\mathrm{b}}$ & $1580.00^{\mathrm{c}}$ & 33.23 \\
Feed conversion ratio & $2.55^{\mathrm{a}}$ & $2.53^{\mathrm{a}}$ & $2.68^{\mathrm{a}}$ & $2 . .80^{\mathrm{b}}$ & 0.07 \\
\hline
\end{tabular}

${ }^{a b c}$ means within the same row with different superscript are significantly different $(\mathrm{P}<0.05)$.

Result showed that treatment effect on feed intake, final body weight, final weight gain, and feed conversion ratio of broilers among the four treatments were significantly $(\mathrm{P}<0.05)$ different. Birds fed diet $\mathrm{T} 1$ $(4680.0 \mathrm{~g})$ and $\mathrm{T} 2(4604.2 \mathrm{~g})$ recorded significantly $(\mathrm{P}<0.05)$ higher feed intake when compared to those on T3 (4546.6g) and T4 (4468.3g). Final body weight and final weight gain also followed similar trend. Results also showed no significant difference $(\mathrm{P}>0.05)$ in feed conversion ratio among those on 0,20 and $25 \%$ cassablood inclusion levels.

The effects of cassablood based-diets on the haematological and serum biochemical indices of finisher broilers are presented in Table 4 and 5 respectively. Blood profile of 
broilers on experimental diets showed significant $(\mathrm{P}<0.05)$ differences only in the triglyceride, cholesterol and total glucose of the birds among the treatment. Cassablood significantly decreased triglyceride at $30 \%$ inclusion level while glucose and cholesterol significantly reduced in all cassablood-based dietary groups. There were no significant differences in all other indices measured. The results of the cost benefit analysis of finisher broilers production with cassablood-based diets are presented in Table 6 .

Table 4: Haematological indices of finisher broilers fed cassablood-based diets

\begin{tabular}{llllll}
\hline Parameters & $\mathbf{T}_{\mathbf{1}}$ & $\mathbf{T}_{\mathbf{2}}$ & $\mathbf{T}_{\mathbf{3}}$ & $\mathbf{T}_{\mathbf{4}}$ & $\mathbf{S E M}$ \\
\hline Packed cell volume (\%) & 31.67 & 32.03 & 32.07 & 32.33 & 0.3 \\
Haemoglobin (g/dl) & 9.80 & 9.70 & 10.01 & 9.93 & 0.33 \\
Red blood cell (x10 /L) & 2.12 & 2.30 & 2.28 & 2.42 & 0.09 \\
White blood cell (x10\%/L) & 23.06 & 23.02 & 23.09 & 23.07 & 0.03 \\
Mean cell volume (FL) & 120.3 & 120.2 & 120.3 & 119.9 & 4.90 \\
Mean corpuscular haemoglobin (pg.) & 41.43 & 40.87 & 40.73 & 41.23 & 1.84 \\
MCH Conc.(g/dl) & 33.43 & 33.53 & 33.33 & 32.93 & 0.70 \\
Differential WBC & & & & & \\
Monocytes \% & 8.67 & 8.56 & 8.62 & 8.46 & 0.71 \\
Neutrophils \% & 7.73 & 7.5 & 7.9 & 7.80 & 0.10 \\
\hline
\end{tabular}

${ }^{a b c}$ means with different superscript differ significantly.

Table 5: Biochemical indices of finisher broilers fed cassablood-based diets

\begin{tabular}{llllll}
\hline Parameters & $\mathbf{T}_{\mathbf{1}}$ & $\mathbf{T}_{\mathbf{2}}$ & $\mathbf{T}_{\mathbf{3}}$ & $\mathbf{T}_{\mathbf{4}}$ & $\mathbf{S E M}$ \\
\hline Triglyceride $(\mathrm{mg} / \mathrm{dl})$ & $137.33^{\mathrm{b}}$ & $136.27^{\mathrm{b}}$ & $137.00^{\mathrm{b}}$ & $132.13^{\mathrm{a}}$ & 3.48 \\
Cholesterol $(\mathrm{mg} / \mathrm{dl})$ & $116.67^{\mathrm{a}}$ & $113.20^{\mathrm{b}}$ & $112.70^{\mathrm{b}}$ & $112.10^{\mathrm{b}}$ & 2.02 \\
Total glucose & $66.13^{\mathrm{a}}$ & $63.67^{\mathrm{b}}$ & $63.62^{\mathrm{b}}$ & $62.93^{\mathrm{b}}$ & 2.48 \\
Total protein $(\mathrm{g} / \mathrm{dl})$ & 5.34 & 5.40 & 5.32 & 5.35 & 0.01 \\
Albumin $(\mathrm{g} / \mathrm{dl})$ & 2.60 & 3.59 & 2.62 & 2.57 & 0.13 \\
Globulin $(\mathrm{g} / \mathrm{dl})$ & 3.33 & 3.32 & 3.33 & 3.34 & 0.02 \\
\hline
\end{tabular}

abc.means with different superscript differ significantly.

Table 6: Economic analysis of cassablood-based experimental diets.

\begin{tabular}{|c|c|c|c|c|c|}
\hline Parameters & T1 & T2 & T3 & T4 & SEM \\
\hline Cost ( $($ /kg Finisher & $118.37^{\mathrm{a}}$ & $113.07^{b}$ & $107.34^{c}$ & $99.84^{\mathrm{d}}$ & 2.34 \\
\hline Feed intake $(\mathrm{kg}) /$ bird & $4.68^{\mathrm{a}}$ & $4.60^{\mathrm{a}}$ & $4.55^{\mathrm{b}}$ & $4.47^{\mathrm{c}}$ & 0.15 \\
\hline Body weight gain $(\mathrm{kg}) /$ bird & $1.83^{\mathrm{a}}$ & $1.82^{\mathrm{a}}$ & $1.70^{\mathrm{b}}$ & $1.58^{\mathrm{c}}$ & 0.11 \\
\hline Cost of Feed ( $) /$ bird & $553.97^{\mathrm{a}}$ & $520.12^{\mathrm{b}}$ & $488.40^{\mathrm{c}}$ & $446.29^{d}$ & 3.34 \\
\hline Cost of Feed ( $(\mathrm{kg}$ body Wt & $302.97^{\mathrm{a}}$ & $285.78^{\mathrm{b}}$ & $287.29^{\mathrm{b}}$ & $282.46^{\mathrm{b}}$ & 2.21 \\
\hline 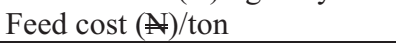 & $118,370^{\mathrm{a}}$ & $113,070^{\mathrm{b}}$ & $107,340^{\mathrm{c}}$ & $99,840^{\mathrm{d}}$ & 2.34 \\
\hline
\end{tabular}

All cassablood-based diets were significantly cheaper than the control in producing $1 \mathrm{~kg}$ broiler chicken (Table 5 ). $25 \%$ inclusion level produced significantly $(\mathrm{P}<0.05)$ best economic gains. However, it did not differ significantly from the rest cassablood-based diets in feed cost per kilogramme of broiler. Feed cost decreased with increased inclusion levels of cassablood with corresponding decrease in weight gain.

\section{Discussion}

The proximate composition of the test ingredient showed that blood component addressed the major deficiencies in cassava (Phuc et al., 2000; Ayasan, 2010) and viceversa. It agreed with the report of Adeyemi 
et al. (2012) that the combination of blood meal and cassava meal gave good protein/energy concentrate with better amino acid content which can be useful in monogastric animal feeding. The favourable performance of birds fed cassablood-based diets comparable with the control diet indicated that cassablood was acceptable to broiler chicken compared with reported rejection (Hassan Khan and Ansari (2007) of high blood meal-based diet (Feedipedia, 2015).

This study showed that some positive chemical reactions could have taken place between cassava and blood before the mixture dried. This could have contributed to utilization of higher level of blood component and thus contrasted Hassan Khan and Ansari (2007) who reported that diets containing more than 3\% blood meal unfavorably influenced feed intake and body weight gain of broiler chickens. The relative consumption and utilization of both the maize-based and cassabloodbased diets is an indication that cassablood could efficiently replace cereal grains and still supply the energy requirements. Nahashon et al. (2005) affirmed that birds will consume sufficient feed to satisfy their energy requirement and is one of the main factors limiting feed intake. The equal performance of birds on $T_{2}$ and those on control diet in terms of the feed intake, body weight gain and feed conversion ratio relative to significantly better performance of those on diets $T_{3}$ and $T_{4}$ showed that broiler chicken conveniently and efficiently utilized $20 \%$ cassablood inclusion than at 25 and 30\% inclusion levels. Probably, the digestive system of broiler chicken could not utilize higher inclusion level of the test ingredient due to manifestation of the imbalance amino acid in blood (Hueze and Tran, 2016) as their quantity increased.
The obtained values in the blood profile were within reported normal ranges (Dukes, 1975; Swenson, 1970; Anon, 1980; Talebi et al., 2005) for broiler chicken. The non-significant $(\mathrm{P}>0.05)$ differences in determined haematological indices among the treatment groups, is a manifestation that cassablood did not pose any health threat to broilers and therefore safe and wholesome for human consumption. Talebi et al, (2005) observed that measurement of haematological parameters provides valuable information for evaluation of health status of man and animals. The marked $(\mathrm{P}<0.05)$ variations in the blood triglyceride of broilers on diet 4 and blood cholesterol and blood glucose of all cassablood-treated groups indicated a positive effect of cassablood as against maize-based diet. It suggests nutritional adequacy of the cassablood for finisher broilers. Esonu et al. (2001) observed that hematological constituents reflect the responsiveness of the animal to its internal and external environments which include feed and feeding.

Data on production cost showed that 20 and $25 \%$ dietary-inclusion levels produced significantly higher $(\mathrm{P}<0.05)$ economic gains on feed cost per kilogram of broiler among all treatments though, all cassablood-based diets were significantly $(\mathrm{P}<0.05)$ cheaper than the control in producing broiler chicken. Oruwari et al. (2003) reported that researchers had concluded that replacement of expensive conventional feed ingredients with cheap and available substitutes represents a suitable strategy at reducing feed costs and encouraging production.

\section{Conclusion}

Results from this study showed that cassablood holds great potentials in poultry feed industry. It supported broiler growth 
and did not pose any health threat to broilers and therefore safe and wholesome for human consumption. The recorded economic advantage of cassablood confirmed it as cheaper alternative to conventional and more expensive ingredients. Therefore, $20-25 \%$ cassablood inclusion level is recommended in broiler diet for optimal, wholesome meat and profit maximization.

\section{References}

Adeyemi, O. A. 2005. Nutritional evaluation of broiler diets formulated with enriched unpeeled cassava root meal fermented with rumen filterates: Ph.D Thesis, University of Agriculture Abeokuta, Nigeria.

Adeyemi, O. A., Adekoya, J. A., \& $S$ o b a y 0, R. A. 2012 . Performance of broilerchicken fed diets containing cassava leaf, blood meal mix as replacement for soybean meal. Rev cient UDO Agricola, 12.

Adeniji, A.A., Ega, L.A., Akoroda, M.O., Adeniyi, A.A., Ugwu, B.O., Balogun A.D. (2005). Cassava development in Nigeria: a country case study towards global strategy for cassava development. Department of Agriculture, Federal Ministry of Agriculture and Natural Resources Nigeria. FAO.Retrieved 22 September 2013.

Aniebo, A. O. 2011. Effect of cassayeast produced from varying c o m b i n a t i o n s of cassava(Manihotesculenta) and brewer's dried yeast (Saccharomyces cerevicea) on b roiler performance. RevistaCientíficaUdoAgrícola 11:161-166.
Aniebo, A. O., Wekhe, S. N. and Erondu, E. S. 2008. Sustainable commercial maggot production (maggotry) for animal and aquafeeds in Rivers State, South South Nigeria. International Journal of Biotech. and Biochem., 4(2), 197-205.

Aniebo, A. O., Owen, O. J. and Erondu, E. S. 2009. Effect of age and method of drying on the proximate composition of maggot meal. Journal of Environmental Toxicology, 113-117.

Aniebo, A. O., Wekhe, S. N. and Okoli, I. C. 2009. 'Abattoir blood waste generation in Rivers State and its environmental implications in the Niger Delta', Toxicological \& Environmental Chemistry, 91: 4, $619-625$

AOAC. 2000. Official Method of Analytical Chemist. 16th Edition . USA: Arlington VA.

Atteh, J. O. 2002. Principles of livestock and practice of livestock feed manufacturing. Ilorin, Nigeria: Adlex Printers.

Ayasan, T. 2010. Use of cassava and products in an imal nutrition.JAFAG, 27:73-83.

Brown, B. A. 1976. Heamatology principles and procedure (2nd ed.). Philadelphia, U S A: Lea and fabigor.

CCAC, 1980. Guide to the care and use of experimental animal. Vol. 1. Ottawa, Ontario,: Canadian Council on Animals care.

Dacie, J. V. and Lewis, S.M. 1984. Practical haematology.6th Edition. Churchill Livingstone. Edinburg,

Donkoh, A. A., Anang, C. C.,Atuahene, C. C., Koomson, B. and Oppong, H. G. 2001. Further studies on the 
Growth performance, blood profile and economic analysis of broilers fed fermented mixture of cassava flour and bovine blood (cassablood) based diets

use of solar-dried blood meal as a feed ingredient for poultry. J. Anim. Feed Sci., 10, 159-167.

Donkoh, A. A., Anang, D. M., Atuahene, C. C. and Hagan, M. A. 2002. Influence of processing temperature on chemical composition of solar-dried blood meal and on performance of broiler chickens. J. Anim. Feed Sci., 11, 497-505.

Dukes, H. H. 1975. Physiology of domestic animal, 18th Ed.. 2nd Printing. (Melvin J. Swenson Edition). Cornell University Press limited. United Kingdom.

Duncan, D. 1995. Multiple Range and multiple F-test. Biometrics; 11 (1): 1-42. Biometrics; 11 (1), 1-42.

Duwa, H., Saleh, B., Lamido, M. and Saidu, A. 2014. Growth, haematological and serum biochemical indices of broiler chickens fed banana peel meal as replacement for maize in the semiarid zone of Nigeria. Journal of Animal and Feed Research, 4( 5), 121-126.

Esonu, B. O., Emenalom, O. O., Udebibie, A. B., Herbert, U., Ekpo, C. F., Okoli, I. C., and Iheukwumere, F. C. 2001. Performance and blood chemistry of weaner pig fed raw mucuna (velvet bean) meal. Tropical Journal of Animal Production and Investigation, 4, 49-55.

FAO. 2010. Paper 1: Livestock Research in Nigeria. www.fao.org

FAO. 2013. FAOSTAT data. Food and Agriculture Organization, Rome: www.fao.org

Feedipedia. 2015. Animal feed resources information system - INRA CIRAD AFZ and FAO. http://www.feedipedia.org/node

Feteris, W. A. 1965. A serum glucose method without precipitation.Am. J. Med. Tech., 31, 17-21

Hassan, Khan, S. and Ansari, N. 2007. Effect of different levels of blood meal on broiler performance during two phases of growth.Int. J. Poult. Sci., 6: 55.

Hueze, V. and Tran, G. 2016.Blood meal.Feedipedia, a programme by INRA, CIRAD, AFZ and FAO. http://www.feedipedia.org/node/2 21 last updated on March 31, 2016.

Jain, N. C. 1986. Schalm's Veterinary haematology ( 4 th ed.). Philadelphia, USA: Lea and Febiger.

Igene, J. 1991. Animal production in Nigeria. (M. Kwanashie, Ed.) Policy Analysis Department, Federa 1 Ministry of Industry.Abuja Nigeria

Kamalak, A., Canbolat, O., Gurbuz, Y. and Ozay, O. 2005. Insitu ruminal dry matter and crude protein degradability of plant and animalderived protein sources of southern Turkey.Small Ruminant Res., 58:135-141.

Nahashon, S. N., Adefope, N., Amenyenu, A. and Wright, D. 2005. Effect of dietary metabolisable energy and crude protein concentrations on growth performance and carcass characteristics of french guinea fowl broilers. Poultry Sci. J. 84:337-344.

Obi, I. 2002. Statistical methods of detecting differences between treatment mean and research methodology issue in laboratory and field experimentation .A.P company ltd. 
Ogbu, C. C. and Amaefule, P. C. 2015. Performance and haematological indices of broiler chickens fed $\mathrm{supple} \mathrm{me} \mathrm{nt} s \quad$ of Gongronemalatifolium, Ocimumgratissimum and Telfariaoccidentalis. Global Journal of Poultry Farming and Vaccination, 3(2), 140-145.

Oruwari, B. M., Aniebo, A. O. and Nkanta, D. M. 2003. Effects of replacing maize with cassava brewers dried yeast blend (cassayeast) on performance of broiler chick and feed cost in southern Nigeria. cassava brewers dried yeast blend (cassayeast) on performance of broilers. Nigeria Journal of Animal Production30 (2), 169.

Pauzenga, U. 1985. Feeding parent stock.Zootecnica International Pp 22-24

Roshlan, P., and Bernet, E. A. 1974. Cholesterol/blood clinical enzyme test. J. Clin Biochem, 12, $403-407$.

Phuc, B. H. N., Ogle, B. and Lindberg, J. E. 2000. Effect of replacing soybean meal with cassava leaf protein in cassava root meal based diets for growing pigs on digestibility and $\mathrm{N}$ retention. Anim. Feed Sci. Technol. 83:223-235

SAS, 2002. SAS Technical Report Package 234 SAS/STAT Software. The GEMOD Procedure.NC.USA.: SAS Institute Inc.
Swenson, M. J. 1970. Physiological properties, cellular and chemical constituents of blood. In M. J. Edition., Duke's physiology of domestic animals. (8th Edn. (M. J. Swenson Edition) ed.). Thaca and London.: Con-stock publishing associates. Cornell University press. Thaca and London.

Swenson, M. J. 1977. Duke's Physiology of domestic animals. Thaca and London: Constock publishing associates a division of Cornell University Press.

Talebi, A., Asri-Rezaei, S., Rozeh-Chai, R. a n d $S$ a h r a e i, R . 2005. Comparative studies on haematological values of broiler strains (Ross, Cobb, Arbor-acres and Arian).International Journal of Poultry Science, 4(8), 573-579.

Taylor, W. B. 2005. Protein sources with differing ruminal degradation characteristics on nutrient digestibility and flows through various segment of the gastrointestinal tract of nonlactating Holstein cows. Louisiana State University Agriculture and Mechanical College.Louisiana

Wintrobe, M. M. 1933. Macroscopic examination of the blood. American Journal of Medical Science, 185, 58-59. 